\title{
The Changing Face of Transnational Business Governance: Private Corporate Law Liability and Accountability of Transnational Groups in a Post-Financial Crisis World
}

Peter Muchlinski

The School of Law, The School of Oriental and African Studies, University of London, pm29@soas.ac.uk

Follow this and additional works at: https://www.repository.law.indiana.edu/ijgls

Part of the Business Organizations Law Commons, Commercial Law Commons, International Law Commons, and the Transnational Law Commons

\section{Recommended Citation}

Muchlinski, Peter (2011) "The Changing Face of Transnational Business Governance: Private Corporate Law Liability and Accountability of Transnational Groups in a Post-Financial Crisis World," Indiana Journal of Global Legal Studies: Vol. 18 : Iss. 2 , Article 4.

Available at: https://www.repository.law.indiana.edu/ijgls/vol18/iss2/4

This Symposium is brought to you for free and open access by the Law School Journals at Digital Repository @ Maurer Law. It has been accepted for inclusion in Indiana Journal of Global Legal Studies by an authorized editor of Digital Repository @ Maurer Law. For more information, please contact rvaughan@indiana.edu.

\section{$\Psi$}

JEROME HALL LAW LIBRARY

INDIANA UNIVERSITY

Maurer School of Law
Bloomineton 


\title{
The Changing Face of Transnational Business Governance: Private Corporate Law Liability and Accountability of Transnational Groups in a Post-Financial Crisis World
}

\author{
Peter MuChLinski ${ }^{*}$
}

\begin{abstract}
This article seeks to critically assess the recently dominant financialized model of corporate law and governance and its contribution to the creation of the "asocial corporation" geared only to the enhancement of shareholder value. This article places corporate law in a wider context of national and international legal developments that, together, create a framework for the financialization of transnational corporate activity. This article shows that a new approach to transnational corporate governance is emerging from a number of sources. These predate the crisis but have been given impetus by it. In particular, three important phenomena are examined: the rise of activist litigation against the parent companies of multinational enterprises (MNEs) for the actions of overseas subsidiaries; the new framework for human rights and business developed by the U.N. Special Representative of the Secretary General; and the increased role of the state as an owner, controller, and regulator of enterprise as a result of the financial crisis and the rise of state-owned and -controlled MNEs from newly industrialized countries. Together, these developments contribute to a reconsideration of the enhanced shareholder value model and the development of a more socially rooted appraisal of the corporation and of corporate law and governance. In addition, new approaches to international economic law instruments and institutional activities can further enhance this reform process, and examples of existing and potential changes are given in the final part.
\end{abstract}

* Professor in International Commercial Law, The School of Law, The School of Oriental and African Studies, University of London, United Kingdom. Please send mail to pm29@soas.ac.uk.

Indiana Journal of Global Legal Studies Vol. 18 \#2 (Summer 2011)

(C) Indiana University Maurer School of Law 


\section{INTRODUCTION}

The end of the first decade of the twenty-first century was a pivotal moment in the history of transnational corporate regulation. The decade began at the height of the neoliberal revolution with its emphasis on financialization, liberalization, privatization, and deregulation. Transnational corporate groups were given free choice of means in their global operations. They could move across borders and adopt whatever business form they wished when the economic case for doing so suited them. There were few regulatory burdens placed on them. In return, states opened their borders so goods, services, and investment could flow freely. At the same time, states offered prime, state-owned industries for privatization through foreign inward investment and reduced barriers to foreign takeovers of privately owned firms. Furthermore, regulatory activity could be reined in, allowing the market to control the outcomes. Controls through competition, tax, and disclosure laws were minimized as they presented a burden for business.

Yet in 2010, we appear to be entering a new world. Where once the liberalization and integration of the global economy was the leitmotif of transnational economic policy, we now hear of increasing concern for national security, both strategic and economic, and of the need to protect "national champions." We also see the return of the state as a controlling owner of industries, particularly in the financial sector. The rise of new players from the BRICs (Brazil, Russia, India, and China) adds further emphasis to the role of the state-owned enterprise and enterprise from the Global (hitherto less developed) South, in world business. ${ }^{1}$ In addition, sovereign wealth funds (SWFs) have arisen as major state-sponsored investors. ${ }^{2}$ On the level of private law, we are seeing the development of new forms of transnational litigation, holding multinational enterprises (MNEs) accountable for harm caused by their

1. See generally U.N. CONFERENCE ON TRADE \& DeV., World INVESTMENT RePorT 2006: FDI FROM DEVELOPING AND TRANSITION ECONOMIES: IMPLICATIONS FOR DEVELOPMENT, U.N. Sales No. E.06.II.D.11 (2006) [hereinafter WORLD INVESTMENT REPORT 2006] (discussing in detail companies from the BRICs and other developing home countries); U.N. CONFERENCE ON TRADE \& DEV., WORLD INVESTMENT REPORT 2007: Transnational Corporations, Extractive Industries and DEVElopment, U.N. Sales No. E.07.II.D.9 (2007) (focusing on state-owned firms from developing countries in extractive industries).

2. See Larry Cata Backer, Sovereign Investing in Times of Crisis: Global Regulation of Sovereign Wealth Funds, State-Owned Enterprises, and the Chinese Experience, 19 Transnat'L L. \& Contemp. Probs. 3, 11-13 (2010) (highlighting how state-owned enterprises have become major components in the global markets as sovereign investors). 


\section{The Changing Face of Transnational Business Governance 667}

overseas operations and, at the level of international law, calls for the extension of human rights responsibilities to corporate actors.

In a word, we are waking up from the thirty-year experiment with the marketization of the global economy, and we are beginning to ask for something else. It is the purpose of this article to examine one aspect of this demand: the issue of private corporate law liability and accountability of transnational corporate groups. As such, this article contributes to the understanding of the complex forces that shape corporate law and which, as Calliess and Zumbansen point out, are leading to transnationalized, hybrid corporate governance regimes that are, "characterised by a particular mixture and interaction of public and private, coordinative and regulatory elements," and which lead to increasingly flexible governance mechanisms that involve new forms of "intertwining formal and informal processes of law making." 3

First, this article will discuss the nature and extent of the deregulatory processes that characterize the neoliberal project, which can be termed "deregulatory globalization," and will examine the role corporate law has played in this. In this regard, the notion of globalization as being deregulatory should be understood as referring to the abolition of regulation that limits corporate freedom of action, as opposed to facilitative regulation which increases corporate free choice of means through permissive laws, a key feature of the neoliberal regulatory order. ${ }^{4}$ The article continues by examining the nature and extent of the changes in policy that allow regulation back in and that challenge the hitherto dominant discourse of corporate law based on neoliberal concerns that enhance shareholder value. This perspective has, to date, retarded avenues of corporate liability and accountability for harm to various stakeholder groups and individuals other than shareholders. Finally, the article will show how these changes impact the development of regulatory possibilities both at the level of liability and accountability, leading perhaps to a new model of post-crisis corporate governance, which moves beyond the narrow issue of agency costs and shareholder protection and which sees the corporation as rooted in social action and responsibility. I argue that this process may, in the end, lead to a reevaluation of what is currently understood as corporate law itself. There is no reason why the model of corporate law, designed in the nineteenth century and operated in increasing isolation

3. Gralf-Peter Calliess \& Peer Zumbansen, Rough Consensus and RunNing CODE: A THEORY OF TRANSNATIONAL PRIVATE LAW 193 (2010).

4. See James Willard HuRSt, The Legitimacy of the Business Corporation IN THE LAW OF THE UNITED STATES, 1780-1970, at 58-111 (1970) (discussing the terms "utility" and "responsibility" to denote the facilitative and regulatory aspects of corporate law in the United States, especially in the period between 1890 and 1970). 
from its wider social reality and impact, should survive in its current form.

Furthermore, it is not clear that there is some stark choice between command and control regulation at one extreme and pure voluntarism and self-regulation at the other. Indeed the process of reevaluation of corporate law arises out of numerous sources including, but not exclusively centered on, the state. The process involves a complex mix of self-regulation, external regulation, interest group lobbying, and private litigation. In particular, this article will consider litigation strategies used by lawyers seeking to make MNEs accountable for their overseas operations; the framework for human rights and business developed by the U.N. Special Representative of the Secretary General on Business and Human Rights (the Special Representative), John Ruggie; and the increased role of the state in the process of oversight and ownership of transnational business entities as illustrations of this multi-sited process of legal change.

\section{DEREgULATORY CORPORATE LAW}

The current and still dominant, but arguably socially redundant, model of corporate law is characterized by a number of features that fit in with the financialization of the global economy. That process has entrenched the asocial tendencies inherent in the classical model of the limited liability joint stock company, the basic tool of modern corporate law. In this context, the term "asocial" denotes the fact that current corporate law, especially the Anglo-American model, which is vaunted by its academic proponents as the most appropriate for the development of the globalized economy, ${ }^{5}$ has led to the detachment of the corporation from its social embeddedness and has created a formal structure that appears to reinforce an atomistic, self-contained system for the organization of capital investment. This system recognizes only the

5. See Henry Hansmann \& Reinier Kraakman, The End of History for Corporate Law, in Convergence aNd PERSistence In CoRPoRate Governance 34-35 (Jeffrey N. Gordon \& Mark J. Roe eds., 2004). See also Rafael La Porta et al., Law and Finance, 106 J. PoL. ECON. 1113, 1116 (1998) (proposing that common law countries are more suited to the development of financial markets because they offer on average better minority shareholder protection than countries following a civil law tradition); Rafael La Porta et al., Legal Determinants of External Finance, 52 J. FINANCE 1131, 1132 (1997) (providing data showing that legal rules of common law countries such as the United States and the United Kingdom provide more protection for creditors and shareholders as compared to civil law countries). But see Katharina Pistor et al., The Evolution of Corporate Law: A Cross-Country Comparison, 23 U. PA. J. INT'L ECON. L. 791, 869-70 (2002) (finding that the above proposition does not withstand closer empirical examination due to other procedural factors). 
assets involved and their formal owners and managers, allowing for those running the enterprise the freedom to disregard the social costs of their actions. These asocial tendencies manifest themselves in a number of features of classical Anglo-American corporate law. ${ }^{6}$

First, there is an exaggerated emphasis on the enhancement of shareholder value as the grundnorm (basic norm) of corporate law and practice. In the words of Calliess and Zumbansen, "[t]he celebration of universally accepted shareholder value standards over many years turned into a triumph over the state's aspiration to regulate the market," despite the existence of different approaches to the organization of capitalism that posit differing levels of balance between limiting and facilitative regulation. ${ }^{7}$ The fetishization of shareholder value leads to a mythologization of the shareholder as owner of the company, even though he or she (or, most commonly, it-a holding company or institutional investor) is little more than a holder of a right to residual revenue from the company. Second, the abuse of limited liability in group structures, especially in regard to the liability of third party involuntary creditors, allows for the irresponsibility of the parent company, and other relevant affiliates, in cases where involuntary creditors have suffered harm as a result of the operations of the group enterprise. Third, there has been an observable weakening of internal governance structures due to an increase in the power of managers, despite the existence of formal rules aimed at the control of such power, as well as the downgrading of formal auditing and other disclosure structures so as to render the activities of the corporation less visible.

I will discuss these issues after a preliminary excursus into the nature and demands of financialization as an ideological process that leads to the creation of the asocial corporation and is underpinned by a network of laws at the national and international level that seek to further the idea of "deregulatory globalization," as well as by advocating a convergence of corporate law toward the Anglo-American model.

6. The term "asocial corporation" is used in preference to the "antisocial corporation" which I feel is too emotive a term. See generally JoEL BAKAN, THE CorPoration: THE PATHOLOGICAL PURSUIT OF PROFIT AND POWER (2004) (regarding the corporation as a pathological force). For a film documentary based on the book, see Mark Achbar, Jennifer Abbot, \& Joel Bakan, The Corporation, THECORPORATION.COM (2003), http://www.thecorporation.com/index.cfm?page_id=46 (providing a YouTube link to the video, divided into 23 parts).

7. CALLIIESS \& ZUMBANSEN, supra note 3 , at 192. 


\section{A. Financialization and Facilitating Globalization through Law}

The term "financialization" has been used in many contexts. ${ }^{8}$ It has been used to describe the rise of financial markets over traditional bank lending as the main source of investment capital; the seeking of profits though financial transactions as opposed to more traditional forms of manufacturing, services, or primary goods industries; as well as the changes in corporate governance theory that place enhanced shareholder value at its heart. ${ }^{9}$ According to Paddy Ireland, this term has its historical pedigree in the Marxist concept of finance capital. ${ }^{10}$ This approach centers on the exploitative aspects of capitalism in the international economy. ${ }^{11}$ Building on Marx's theories of the concentration of capital, labor exploitation, and the division of labor in society, ${ }^{12}$ subsequent writers have developed theories of monopoly capitalism and imperialism to explain the operation of international capitalism. ${ }^{13}$

The thesis is that the tendency of the national capitalist industry to move toward monopolization (used here to denote not single firm dominance but market concentration in general) prompts the export of capital. The character of the capital exported is significant. It is described as "finance capital," a term denoting the merger between financial capital

8. See Paddy Ireland, Financialization and Corporate Governance, 60 N. IR. LEGAL Q. 1,4 (2009).

9. See Paul H. Dembinski, Finance: Servant oR Deceiver? Financialization at THE Crossroads 1-2, 5-6 (Kevin Cook trans., Palgrave MacMillan 2009) (2008); Greta R. Krippner, The Financialization of the American Economy, 3 SocIO-ECON. REv. 173, 181 (2005). See also Gerald A. Epstein, Introduction: Financialization and the World Economy, in Financialization and THE WoRld Economy 3-16 (Gerald A. Epstein, ed., 2005) (exploring how "financialization" has transformed domestic and international economies); FINANCIALIZATION AT WORK 24-25 (Ismail Erturk et al. eds., 2008) (discussing the changing meaning of the term "financialization" and the growing importance of the capital market).

10. See Ireland, supra note 8, at 5-6.

11. See ANTHONY BREWER, MARXIST THEORIES OF IMPERIALISM: A CRITICAL SURVEY 88. 95 (2d ed. Routledge 1990) (1980) (discussing in full the development of the concept of "finance capital" and its importance to "classical Marxist theories of imperialism"); PETER T. MUCHLINSKI, MULTINATIONAL ENTERPRISES AND THE LAW 92-93 (2d ed. Oxford Univ. Press 2007).

12. See Karl Marx, Capital Vol. I: The Process of Capitalist Production, 350-368, 612-713 (Frederick Engels ed., Samuel Moore \& Edward Aveling trans., Int'l Publishers Co. 1967) (1887).

13. See, e.g., RUdolf Hilferding, Finance CaPital: A Study of the Latest Phase of CAPITALIST DEvelopment 8-10 (Tom Bottomore ed., Morris Watnick \& Sam Gordon trans., Routledge \& Kegan Paul 1981) (1910) (explaining the connection between "monopolies" and "imperialism"); NIKOLAI BUKHARIN, IMPERIALISM AND WORLD ECONOMY (1972) (examining facts of the world economy as they relate to imperialism). These theories were popularized by a pamphlet authored by V. I. Lenin. See V. I. LENIN, IMPERIALISM: THE HIGHEST STAGE OF CAPITALISM 104-05 (1975). 
(money capital dealt with by banks and other financial enterprises) and industrial capital (capital employed by productive enterprises). This fusion of concepts, introduced by Hilferding, permits the view that, for the purposes of international investment, the functions of financing and controlling the investment can be united in a single enterprise. ${ }^{14}$ As Anthony Brewer notes, "if this generalisation of the concept is accepted, it opens the way to regarding the large multinational companies of today as part of finance capital," 15 since such companies engage in both of the abovementioned functions.

Given the role of MNEs as a potent instrument of finance capital, it is not surprising to see that their activities have encouraged the financialization of business practices, including the furtherance of enhanced shareholder value as the cornerstone of corporate conduct. ${ }^{16}$ This has impacted not only national laws but also the organization of transnational business law generally. Indeed, in order to fully understand the limiting functions of corporate law as a means of regulating modern companies, it is necessary to view this field in a wider legal context. Company or corporate law does not exist in a vacuum. It is intimately connected with other fields that, together, provide the legal underpinnings of the neoliberal global system. Thus, before company law itself is considered in the next subsection, it is necessary here to list and describe the other main fields of law that contribute to the development of this system.

The starting point for this system, as noted above, is to offer the best conditions for the maximization of returns on investment for the MNE. This requires the facilitation of firm movement across the global economy so that it can make the best use of the combination of its ownershipspecific advantages with location-specific advantages in host countries. ${ }^{17}$ In turn, this requires the reduction of investment risk either by way of protective laws or through insurance. The regulation of labor markets through labor laws is also a significant element in investment risk reduction. A further element concerns the finance of investments and preferential access to capital markets.

In regard to free movement, in addition to easy incorporation through company law, a matter to be discussed below, the law relating to trade and investment liberalization plays a significant role. These are issues of international or regional law. ${ }^{18}$ At the international level, the existence of

14. See HILFERDING, supra note 13 , at 223.

15. BREWER, supra note 11 , at 93 .

16. See DEMBINSKI, supra note 9, at 113.

17. See generally JOHN H. DUNNING \& SARLANNA M. LUNDAN, MULTINATIONAL ENTERPRISES AND THE GLOBAL ECONOMY 79-144 (2d ed. 2008).

18. MUCHLINSKI, supra note 11 , at 238-39. 
WTO law seeks to control protectionist tendencies in national trade laws and practices that operate at the border to limit the penetration of the local market by competitive imports of goods and services. Such restrictions can also impede the spread of global production chains that may rely on reduced barriers to trade for their continued existence. At the same time, international investment law seeks to remove barriers to entry and establishment through the extension of principles of nondiscrimination to the pre-entry phase of an investment. The WTO system is multilateral and has achieved high levels of acceptance by states. By contrast, the extension of pre-entry protection to investors under international investment law has been limited to a number of Bilateral Investment Treaties (BITs) entered into by the United States and Canada, and more recently Japan, as well as certain bilateral and regional Free Trade Agreements (FTAs). In addition, the General Agreement on Trade in Services (GATS) allows for the protection of nondiscriminatory rights of entry and establishment to service providers who have a commercial presence in the host country, and it has granted sectoral access to foreign investors under Article XVI of the GATS. At the regional level, numerous Economic Integration Agreements (EIAs) contain rights of entry and establishment. Though not the most dominant approach of BITs, the increasing use of pre-entry protection in more recent agreements is significant because it shows a growing trend in investment liberalization through law. This process has continued despite increased anxiety over national economic and strategic security, with only a handful of states currently renouncing their BITs. ${ }^{19}$

As noted above, investment risk is reduced by way of protective laws, which ensure the competitive advantage of investors is not undermined by host countries' regulations. This requires that the internal laws of the host country both facilitate the investment and protect its economic value. Of particular importance are the following: first, the protection of the firm's innovations and brands as proprietary rights; second, the creation of structures conducive to the growth of large corporations; and third, the control of local labor markets to ensure favorable costs of labor. The first task can be met by a system of intellectual property rights protection, coupled with an effective system of contract law, which can regulate the use of the firm's property in the hands of a licensee. The protection of intellectual property rights is reinforced by international law under the WTO Agreement on Trade-Related Aspects of Intellectual Property Rights (TRIPS) Agreement. This entrenches certain protective standards as

19. See U.N. Conference on Trade \& Development, Recent Developments in International Investment Agreements, IIA MoNITOR, no. 3, Mar. 7, 2009, at 1, 6, http://www.unctad.org/templates/Page.asp?intItemID=3784\&lang=1. 


\section{The Changing Face of Transnational Business Governance 673}

international obligations that limit state sovereignty in this regard. ${ }^{20}$ This is a significant matter given that it is open to debate how far protection of intellectual property rights is needed to conserve the competitive advantages of firms with considerable market power such as MNEs or to further development. ${ }^{21}$

The second task can be met by laws that allow a large joint stock fund to be created and an ownership of shares to be held by one company in another, without restrictions on the nationality of the shareholding company. ${ }^{22}$ This may also require the repeal of restrictive national investment screening laws. ${ }^{23}$

The third task is a function of labor law, which regulates the conditions under which employees may be contracted to work. It is an essential aspect of the economic activity of the enterprise and is intimately linked with the organization and governance of corporations. ${ }^{24}$ Labor laws

20. See Sol Picciotto, Regulating Global Corporate Capitalism ch. 9 (forthcoming spring 2011) (on file with author).

21. See Sanjaya Lall, The Patent System and the Transfer of Technology to LessDeveloped Countries, $10 \mathrm{~J}$. WORLD TrADE L., no. 1, 1976 at 1, 8-11. See also U.N. CONFERENCE ON TRADE \& DEV., WORLD INVESTMENT REPORT 2005: TRANSNATIONAL CORPORATIONS AND THE INTERNALIZATION OF R\&D, at 101-2, U.N. Sales No. E.05.II.D. 10 (2005). This report shows that the protection of intellectual property rights might make little sense given the particular level of technological capability a developing country enjoys. If the technological functions in the host country are basic, then the presence or absence of IPR protection is irrelevant. If those functions are imitative and adaptive, then a regime of strong IRP protection may actually discourage investment as it will cut off the producer from access to the source technology from which imitation through reverse engineering occurs.

22. MUCHLINSKI, supra note 11 , at 33-34.

23. According to United Nations Conference on Trade and Development (UNCTAD), such laws have been progressively liberalized in many, but not all, countries over the 1990 s and the early 2000s. However, in recent years some countries have increased controls over entry and establishment especially on national security grounds. The reader can find detailed statistics produced on an annual basis in the first chapter of each of the UNCTAD annual World Investment Reports from 1991 to 2009 and in chapter three, section A of the 2010 report. See U.N. Conference on Trade \& Dev., World Investment Reports 1991.2010, available at http://www.unctad.org/Templates/Page.asp?intItemID $=1485 \&$ lang=1 (to view a particular year: click on the year (i.e. "WIR 2008"), click "Downloads," and then click "Full report").

24. See John W. Cioffi, Governing Globalization? The State, Law, and Structural Change in Corporate Governance, 27 J.L. \& SoC'Y 572, 574 (2000). See also CALLIESS \& ZUMBANSEN, supra note 3, at 190-91 (citing Cioffi with approval). Calliess and Zumbansen see a gap in scholarship between corporate and labor law, which they say have been living separate "parallel" lives. Id. at 191. It is apposite to point out that such scholarly linkage was pioneered as early as the 1960 s by Professor Bill Wedderburn, Emeritus Cassell Professor of Commercial Law at the London School of Economics. He authored the pioneering work, The Worker and the Law, and was the editor of the leading English law company law textbook, Gower's Principles of Modern Company Law, through numerous editions before he retired. I was fortunate to have studied these linkages with Professor 
may be highly protective of employee rights or they may limit them to various degrees. In a neoliberal context, the aim of labor law is to ensure that labor costs are placed at an economically efficient level so as to increase the enterprise's return on equity. ${ }^{25}$ Thus the tendency would be to limit labor rights to the extent possible without compromising basic international labor standards, as laid down in the ILO Conventions. In some countries, the imperative to attract mobile international investment may lead to a curtailment of even the most basic labor rights, creating a race to the bottom, although the economic case for such restrictions is far from clear. ${ }^{26}$ Indeed, it is also arguable that a high level of employee protection and a guarantee of trade union rights actually ensure a better investment environment. ${ }^{27}$

International investment laws based on BITs with home countries can supplement the protective function of host country laws. Unlike the United States BITs, the bulk of Canadian and recent Japanese BITs only apply to the postentry phase of the investment. Once established, the investor and the investment ${ }^{28}$ will enjoy a range of rights over the host country's authorities. In particular, most agreements will contain a nondiscrimination standard based on most-favored-nation treatment, which ensures the same or no less favorable treatment of foreign investors from different countries, and national treatment, which ensures the same in relation to domestic investors. In both cases, the investors should be in like circumstances to benefit from this protection. In addition, many agreements have a fair and equitable treatment provision, which allows a review of administrative action against an absolute standard of good governance based on the investor's legitimate expectations as to the value of the investment and to the treatment that it should receive. ${ }^{29} \mathrm{In}$ addition, most BITs contain a provision requiring full and effective compensation for any taking done in accordance with law, which must be for a public purpose and nondiscriminatory. More recently, such provisions have been used to protect investors and investments against regulatory

Wedderburn, who encouraged the inclusion of a chapter on labor relations in my work. See MUCHLINSKI, supra note 11 , at 473.

25. See DEMBINSKI, supra note 9, at 116-17.

26. See Bob HePple, Labour laws aNd Global Trade 13-15 (2005) (showing the weaknesses of the economic case for reducing labor standards).

27. Id. at 15-21.

28. These rights are often broadly defined to cover any kind of asset owned or controlled by the investor. See U.N. CONFERENCE ON TRADE \& DEV., SCOPE AND DEFINITION, at 24-28, U.N. Sales No. E.11.II.D.9 (2011).

29. See Rudolf DOLZER \& CHRISTOPH SCHREUER, PRINCIPles OF InTERNATIONAL INVESTMENT LAW 17-24 (2008) (providing an overview of the main elements of BITs); see also M. SORNARAJAH, THE INTERNATIONAL LAW ON FOREIGN INVESTMENT 225-76 (2010) (offering a more critical account of BITs). 
The Changing Face of Transnational Business Governance 675

takings in which the title to the asset has remained in the investor's hands but the economic value of the investment has been drastically reduced as a result of fiscal or other regulatory measures. Other standards of protection include protection against loss due to civil unrest or commotion, the free transfer of capital, and the duty to obey contractual obligations entered into with the investor.

All of these standards can be enforced through the investor-state dispute settlement provisions of the BIT. In current practice, an agreement typically gives the investor the right to choose the method of dispute settlement. The choice is usually between national or international dispute settlement systems. In the latter case, a further choice is given between ad hoc international arbitration and institutional arbitration, usually under the auspices of the International Centre for the Settlement of Investment Disputes (ICSID). Once the investor has made a choice, other alternatives are excluded. This freedom has given rise to considerable concerns in that the investor is given a unilateral right to exclude national systems of dispute settlement and to internationalize the dispute with the host country. This may put the settlement of a major issue, with far reaching consequences for national policy making, into the hands of international arbitrators who are neither an international court nor democratically accountable persons. It has led to a view that this system lacks political legitimacy, unlike that of a court system. ${ }^{30}$

The threat of political risks, such as expropriation, is a factor that will increase the perceived costs of investment in a host state. However, these costs may be reduced if insurance is provided against political risk. ${ }^{31}$ This kind of coverage may be available through private insurers, although this has not always been easy to obtain given the difficulties of quantifying the risk involved. Thus, to ensure the availability of political risk coverage, the governments of capital-exporting states have sponsored public sector or mixed public/private sector schemes. Such schemes have traditionally focused on developing host states and have been administered as part of the home state's foreign aid program, although some schemes, such as the U.K. Export Credit Guarantee Department (ECGD), are directed at foreign trade and investment generally. ${ }^{32}$ Therefore, such schemes may be more than merely an insurance service; they may be an instrument of the home state's foreign economic and development policy. Such schemes may also influence the extent of corporate liability for certain types of actions that harm the environment or threaten the observance of human rights, in that the allocation of insurance could be made conditional on adequate

30. See generally GUS VAN HaRTEN, INVESTMENT TREATY ARBITRATION AND PUBLIC LAW (2007) (examining the system of investment treaty arbitration in depth).

31. MUCHLINSKI, supra note 11 , at 617.

32. See Export and Investment Guarantees Act, 1991, c. 67, § 1 (U.K.). 
environmental and human rights impact assessments. In addition to national schemes, the World Bank Convention Establishing the Multilateral Investment Guarantee Agency of 1985 (MIGA) established a multilateral system for investment insurance against stipulated political risks in the host state. ${ }^{33}$

Turning to the facilitation of finance for MNE operations, this can be met through the liberalization of access to international capital markets. This has been achieved through market deregulation. In particular, the ending of restrictive trading practices on the major stock exchanges of the world in the 1980s and 1990s has led to the globalization of these markets and the capacity of MNEs to raise capital through global share issuances. ${ }^{34}$ In addition, the liberalization of the rules relating to takeovers has allowed for increased use of the market for corporate control as a means of entering overseas markets and acquiring valuable capital assets. The key here is the principle of nonfrustration whereby the shareholders of a company targeted for takeover can decide whether to accept a bid for the company regardless of the views of the board. ${ }^{35} \mathrm{~A}$ further issue in relation to capital markets is the role of prudential regulation. In general, extensive regulatory structures exist both at national and international levels in this regard. ${ }^{36}$ However, the major problem has been one of regulatory failure on the part of the regulators and culpable noncompliance by the banks, as demonstrated in the collapse of the Bank of Credit and Commerce International (BCCI) in 1991 and the more recent banking crisis of 2007 through $2009 .{ }^{37}$

33. World Bank: Convention Establishing the Multilateral Investment Guarantee Agency, Oct. 11, 1985, 24 I.L.M. 1598.

34. See Peter Dicken, Global Shift: Mapping the Changing Contours of the WORLD ECONOMY 377-80 (6th ed. 2011).

35. See Paul L. Davies, Gower and Davies' Principles of Modern Company Law 985-86 (6th ed. 2008); Ireland, supra note 8, at 23. See generally Paul Davies \& Klaus Hopt, Control Transactions, in THE ANATOMY OF CoRPORATE LAW 225 (Rainer Kraakmann et. al. eds., $2 \mathrm{~d}$ ed. 2009) (considering the different legal methods for dealing with problems that occur when individuals attempt to gain control of a company through the acquisition of large numbers of voting shares in that company).

36. See ANDREAS F. LOWENFELD, INTERNATIONAL ECONOMIC LAW 804.45 (2d ed. 2008). See generally Howard Davies \& David Green, Global Financial Regulation: The ESSENTIAL GUIDE (2008) (describing in detail the current international system of financial regulation and offering recommendations for changes to this system).

37. See generally LORD JUSTICE BINGHAM, INQUIRY INTO THE SUPERVISION OF THE BANK OF CREDIT AND COMMERCE INTERNATIONAL, 1992-3, H.C. 198 (investigating the systematic failure of regulators to uncover the criminal activity of BCCI); VINCE CABLE, THE STORM: THE WORLD ECONOMIC CRISIS AND WHAT IT MEANS (2009) (tracing the origins of the global economic crisis); GILLIAN TETT, FOOL'S GOLD: HOW THE BOLD DREAM OF A SMALL TRIBE AT J.P. MORGaN WAS CoRRUPTED BY WALL STREET GREED AND UNLEASHEd A CATASTROPHE (2009) (indicting bankers, regulating agencies, and ratings agencies for colluding to create a financial system that was doomed to collapse). 
The Changing Face of Transnational Business Governance 677

\section{B. Financialization and Corporate Law}

Against this wider background, corporate law operates at the national level to create a system of corporate governance that facilitates freedom of economic action for the benefit of shareholders. The interaction of corporate strategy with market organization and stimulus spurred the evolution of modern corporate governance structures. ${ }^{38}$ This led to the development of multidivisional corporations and the separation of ownership and control between managers and shareholders, with the latter remaining, at best, nominal owners of the company while controlling power lay with the managers. ${ }^{39}$ It was this effect of corporate growth that led to the development of agency-based theories of corporate governance. These theories sought ways of avoiding the problem that uncontrolled managers may act in their own interests, not in the best interests of the shareholders, thereby undermining the basic promise made between the company and its shareholders that the company would be run in the shareholders' best interests.

Consequently, the main thrust of agency-based theories is the reduction of agency costs, that is, those costs that arise when managers fail to act in the best interests of the company and hence of the shareholders. The principal cost that needs to be controlled is the misallocation of funds away from the shareholder toward the manager. Based on the initial promise made between managers and shareholders, the theory develops a contractual analysis of the enterprise and posits that it is no more than a nexus of contracts between the managers and the shareholders. ${ }^{40}$ Those contracts aim to protect the shareholders as the residual risk-bearers of the company. Thus, the main thrust of these arrangements is to enhance shareholder value. This is justified by the fact that shareholders take the greatest risks as they have no contractual guarantee of a return on their investment, unlike voluntary creditors who have entered into contracts with the company. The main

38. See generally ALFRED D. ChANDLER, JR., STRATEGY AND STRUCTURE: CHAPTERS IN THE HISTORY OF THE AMERICAN INDUSTRIAL ENTERPRISE (1962) (discussing how four major American corporations dealt with administering their expanding businesses by decentralizing their corporate structure); ALFRED D. CHANDLER JR., THE VisIBLE HAND: THE MANAGERIAL REVOLUTION IN AMERICAN BusinesS (1977) (discussing how the managerial capitalism of the modern business enterprise took the place of market mechanisms in coordinating the activities of the economy and allocating its resources).

39. See Adolf A. Berle \& Gardiner C. MEANS, The Modern Corporation and PRIVATE PROPERTY 128-31 (1967).

40. See Michael C. Jensen \& William H. Meckling, Theory of the Firm: Managerial Behavior, Agency Costs and Ownership Structure, 3 J. FIN. ECON. 305, 310-11 (1976) (arguing that many organizations are a legal construct of overlapping contract relationships among individuals). 
mechanism for controlling managers in this situation is the market itself. Inefficient firms will not attract shareholder interest or will lead to takeovers by more efficient management teams, and so the market offers the best discipline for managers to run their companies efficiently.

This theoretical model has been highly influential in the AngloAmerican world. It fits easily with the ideological assumptions of neoliberalism that have dominated the political scene since the election of Margaret Thatcher and Ronald Reagan at the beginning of the 1980s. It is also a model open to profound criticism from a corporate law perspective. In particular, it appears to deny normative force to the corporate entity itself, whose main commercial and legal purpose is to replace a myriad of inefficient contractual transactions with a collectively organized and managed entity, capable of owning and directing the application of its own capital funds, separate from those of its owners, for commercial purposes. ${ }^{41}$ In addition, it makes the shareholder no longer the formal owner of the company but a mere contractual claimant. ${ }^{42}$

The agency approach also has serious implications for any attempt to add social obligations to the range of corporate duties. First, it can prevent seeing the corporation as a collective actor based on coordinated management, and it could justify the rejection of a duty to observe such wider obligations since corporations are no more than "legal fictions which serve as a nexus for a set of contracting relationships among individuals." 43 Second, an agency approach is likely to see a commitment to observe social obligations as a threat to shareholder primacy. Should managers take steps to comply with such obligations, they can only be doing so by reason of some contractual commitment to the holders of these rights. As such, this would be an illegitimate extension of their actions since it would fall outside the range of actions required to fulfill their agency obligations toward shareholders. It sets up a competing set of claimants whose risks in relation to the firm are virtually nonexistent, at least in strict economic terms. The holders of social claims against the corporation have invested nothing in the

41. See Melvin A. Eisenberg, The Conception That the Corporation is a Nexus of Contracts, and the Dual Nature of the Firm, 24 J. CORP. L. 819, 820 (1999).

42. Id. at 825 .

43. Jensen \& Meckling, supra note 40 , at 310 . The authors define "legal fiction" as "the artificial construct under the law which allows certain organizations to be treated as individuals." Id. at $310 \mathrm{n} .12$. However, this definition is meaningless because corporations are not individuals but complex collective enterprises. This definition is at odds with, for example, the organization liability approach taken under the English law of corporate manslaughter, which clearly establishes the corporate actor as the guilty party, not on the basis of some fictive personality, but on the basis of its organizational actions. 
company so they cannot require anything from managers, while the latter have no right to exercise their managerial power to meet such third party claims. Such is the logic of an agency-based approach. Where the law externalizes social costs, the result is that managers do not need to care about social obligations, and shareholders can hold claims against managers who do, as this would amount to a breach of duties to the company and indirectly to the shareholders.

These tendencies are indeed observable when it comes to the issue of making claims against group enterprises. The classical model of the limited liability joint stock company assumes that the owners are actual persons who require the corporate form to engage in the risks of business. ${ }^{44}$ It does not contemplate the situation where one company owns and controls another. This creates special problems in relation to one class of actors: tort victims, who are often referred to as involuntary creditors of the company that has caused them injury. Involuntary creditors have no chance to bargain with the corporation over the allocation of risks, unlike voluntary creditors, who enter into contracts with the company. ${ }^{45}$ Yet, they may have to bear the risk of loss if the corporation does not possess sufficient assets to compensate them for their injuries. This is due to limited liability, which allows only the actual capital of the company to be used to compensate tort victims. The assets of the shareholders can only be touched to the extent of the value of their shares in the company. When the controlling shareholder is another company, it too benefits from limited liability in the same way as an individual shareholder. However, this may lead to significant undercompensation of tort victims, or even no compensation, if the parent has used the separation between itself and its subsidiary to insulate itself from liability.

A further example of such asocial corporate law arises out of the process whereby, in recent years, managers have strengthened their position in the company by weakening internal corporate governance structures. For example, this problem lies at the heart of the Enron scandal. ${ }^{46}$ Specifically, the key problem lies with the dilution of the

44. Peter Muchlinski, Limited Liability and Multinational Enterprises: A Case for Reform?, 34 CAMBRIDGE J. ECON. 915, 918 (2010).

45. See Henry Hansmann \& Reinier Kraakman, Toward Unlimited Shareholder Liability for Corporate Torts, 100 YALE L.J. 1879, 1920-21 (1991) (discussing the differences between involuntary and voluntary creditors and how they allocate risk).

46. See Peter T. Muchlinski, Enron and Beyond: Multinational Corporate Groups and the Internationalization of Governance and Disclosure Regimes, 37 CONN. L. REv. 725, 726-35 (2005) (summarizing the main reasons for Enron's collapse). See generally John C. Coffee Jr., What Caused Enron? A Capsule Social and Economic History of the 1990s, 89 CORNELL L. REV. 269, 302 (2004) (discussing a wide variety of explanations for the corporate governance failures of 2001 to 2002). 
separation of roles between managers, shareholders, and finance officers within the company. As more managers became shareholders in their companies as a result of stock option schemes comprising part or all of their remuneration, the apparent conflict of interest between manager and shareholder, traditionally embodied in the agency costs approach to corporate governance, apparently disappeared. ${ }^{47}$ Managers and shareholders were now on the same side and wanted the same thing - the highest possible share prices. Thus, the company director's principal duty was to act in the best interests of the company-that is, in the best interests of the shareholder- which became a duty to act in his or her own interests! This resulted in the very high remuneration packages that have been the focus of considerable public criticism, whether in financial or other companies. ${ }^{48}$ In the United States, this trend was furthered by regulatory changes in the 1990s that offered tax deductions for performance-based compensation of corporate directors, encouraging the use of stock options as a principal means of remuneration. In addition, Federal Accounting Standards Board (FASB) accounting rules did not require companies to include options as an expense. A proposed change to these rules was overturned by the U.S. Senate in 1994, allowing such payment packages to be effectively free on the corporate balance sheet. 49

The perverse incentives of stock options resulted in a more cavalier attitude among company directors toward anything other than the short-term value of their share price, inducing them to cut corners on corporate governance compliance where this could affect the rise in short-term share values. ${ }^{50}$ In the Enron case, this led to out-and-out fraud and a failure to observe any duty to serve the interest of the company, which predictably collapsed as soon as the full extent of these actions became known. ${ }^{51}$ It also led to the reduction of information offered to the board, thereby restricting the ability of the nonexecutive directors to act in their capacity as internal watchdogs over the executive directors. ${ }^{52}$

47. See Ireland, supra note 8, at 19.

48. See id.

49. See Frank Partnoy, Infectious Greed: How Deceit and Risk Corrupted the FinanClal MARKETS 155-57 (rev. ed., Public Affairs 2009) (2003).

50. See id. at 211-14; DEMBINSKI, supra note 9, at 114-15.

51. See PARTNOY, supra note 49, at 294-96, 346-47; Coffee, supra note 46, at 275-79; Muchlinski, supra note 46, at 728.

52. For more on the problems of nonexecutive directors on boards of Anglo-American companies, see MUCHLINSKI, supra note 11, at 342-44 (discussing how the independent nature of nonexecutive directors and the requirement that nonexecutive directors meet separately as a group could encourage a policy of nondisclosure to the board, thus limiting the ability of the nonexecutive directors to be internal watchdogs). 
In regard to finance officers, they should act as the first line of defense against inaccurate accounting. However, the Enron case and other accounting scandals show that these financial officers could not prevent the scandals. ${ }^{53}$ This is intimately linked to the way in which international businesses like Enron have changed. In the first place, so as to reduce overall operating costs, many companies have cut their finance departments as routine finance functions, such as payroll, benefits, and expenses, have been outsourced. As a result, the role of finance officers has changed from that of an accountant and controller of historic business costs to a strategic financial analyst of future business opportunities. Thus, their role has become more closely linked to that of the executive officers and their projects. When coupled with significant change in corporate business functions, as in the case of Enron moving into new energy trading activities, finance officers are actively engaged in completely new sets of financial issues and in ensuring effective financial performance in these circumstances. Thus, finance officers at Enron were active in developing many of the financial techniques used to inflate the value of Enron's trading activities, thereby losing sight of their responsibilities as financial controllers. Ensuring the return of finance officers to such a role is key to avoiding the types of managerial excesses that characterized the Enron case and other accounting scandals.

As an alternative to the Anglo-American unitary board structure, companies in Germany have a two-tier board. ${ }^{54}$ Arguably, this makes the executive directors more accountable, as the supervisory board has oversight and is separate from the management board. However, the problem of executive director accountability does not disappear by use of the two-tier board model. It is as equally possible for a determined chief executive to keep a supervisory board in the dark as it is for a unitary board. For example, when Daimler Benz and Chrysler merged in May 1998, Jurgen Schrempp, the Daimler Benz chief executive at the time, only informed the supervisory board of the German company the day before the merger was announced, while the unitary board of Chrysler learned of the plan in February 1998 and discussed negotiations throughout. ${ }^{55}$ Ahold had a two-tier board structure, but this did not

53. See Muchlinski, supra note 46, at 761-62. See also Robert Howell, How Accounting Executives Looked the Wrong Way, FIN. TIMEs (London), Aug.13, 2002, at 11 (discussing how financial officers failed to prevent the aggressive accounting and reporting practices by their companies).

54. See Mads andenas \& Frank Wooldridge, European Comparative Company LAW 297.320 (2009). The two-tier board is also an optional structural choice for companies in France and the Netherlands, as opposed to a single board. Id. at 286, 368.

55. The Way We Govern Now, ECONOMIST, Jan. 11, 2003, at 61, 62. 
prevent the accounting abuses that arose in the course of its operations. ${ }^{56}$ Nor has the two-tier structure prevented the development of a culture of accommodation between the supervisory and management boards of European companies following this approach. For example, the trial in Germany of certain Mannesmann directors revealed a willingness on the part of nonexecutive directors to approve pay packages for executive directors, arising out of the takeover of Mannesmann by Vodafone, which German prosecutors regarded as illegal. The accused, of which four were nonexecutive directors, were acquitted in July 2004, but a retrial of the case was ordered in 2005.57 The case ended in a settlement whereby the defendants agreed to pay substantial fines without any admission of guilt. 58 Indeed, the OECD Principles of Corporate Governance assert that "there is no single model of good corporate governance," and "they do not advocate any particular board structure and the term 'board' as used in [the] document is meant to embrace different national models of board structures found in OECD and non-OECD countries."59

Such internal governance failures are supposed to be reduced by the existence of external governance mechanisms. In particular, the auditing function and the regulatory oversight of the corporation by state regulatory agencies, especially in relation to the issue of securities and tax liability, should ensure transparency and clarity in the overall picture of the corporation's activities. Unfortunately, these functions have also failed in the race to secure the greatest financial return from the corporate system. ${ }^{60}$ Most notably in the Enron case, the auditor, Arthur Andersen, authorized accounts that failed to show a true and fair view of the company's situation. In particular, the use of off-balance sheet entities, into which Enron debt was poured and which were set up

56. See Europe's Enron, Economist, Mar. 1, 2003, at 63, 64.

57. See Patrick Jenkins, Appeal Lodged Against Trial Acquittals, Fin. TIMEs (London), July 24, 2004, at 6; Patrick Jenkins, Court Clears Bosses over Bonuses, FIN. TIMES (London), July 23, 2004, at 28; Mark Landler, Top Banker to be Retried in Germany, N.Y. TIMES, Dec. 22, 2005, at C21.

58. Bundesgerichtshof [BGH] [Federal Court of Justice] Dec. 21, 2005, 50 Entscheidungen des Bundesgerichtshofes in Strafsachen [BGHSt] 331 (F.R.G.), available at http://www.hrr-strafrecht.de/hrr/3/04/3-470-04.php; Bernard Black et al., Legal Liability of Directors and Company Officials Part 2: Court Procedures, Indemnification and Insurance, and Administrative and Criminal Liability (Report to the Russian Securities Agency), CoLuM. BUS. L. REV., 2008, at 1, 145-46.

59. Org. for Econ. Co-Operation \& Dev. [OECD], OECD Principles of Corporate Governance, at 13 (2004), available at http://www.oecd.org/dataoecd/32/18/31557724.pdf.

60. See generally A. LARRY ELLIOTT \& RICHARD J. SCHROTH, HOW COMPANIES LIE: WHY ENRON Is JUST THE TIP OF THE ICEBERG (2002) (arguing that the Enron disaster exemplifies the dire need for corporate law reform); PARTNOY, supra note 49 (discussing the various financial scandals that led to the 2008-2009 financial crisis). 
The Changing Face of Transnational Business Governance 683

with the active cooperation of third parties who formally, but not actually, controlled them, was approved. This was done because the Securities and Exchange Commission (SEC) accepted such accounting practices in principle.

In addition, the SEC accepted the principle of mark-to-market accounting, which permits the full, projected future value of a futures trading transaction to be displayed on the balance sheet, rather than the actual periodic historical earnings on the transaction as it progresses. In response to Enron, the Sarbanes-Oxley Act in the United States introduced reforms in auditing practice, a prohibition on auditors also serving as financial consultants to the companies they audit, and strict criminal penalties for noncompliance.$^{61}$ By contrast, in the United Kingdom, the Combined Code of Corporate Governance retains the voluntary "comply or explain" standard, which leaves to the company the decision whether to follow the requirements of the Combined Code and explain its reasons in its annual report. ${ }^{62}$

\section{Challenges to Deregulatory Corporate LaW}

Law has played a significant part in the process of financialization and deregulation of corporate activities. The wider environment for corporate action has been increased through international trade and investment liberalization measures; the competitive advantages of firms have been secured through intellectual property and contract laws; the freedom of establishment has been eased by permissive corporate laws and the removal of restrictive investment screening laws in many countries; and company and securities law has allowed for, or perhaps more accurately ignored, changes in internal corporate governance that further entrench the financialization of corporate actions. However, this approach is called into questioned by a number of challenges to the deregulatory model of corporate law.

These challenges do not uniquely come from within company law. Indeed, company law remains largely rooted in its enhanced shareholder value straightjacket, at least in the Anglo-American world. ${ }^{63}$ Equally, the much misunderstood, but apparently more socially

61. See MUCHLINSKI, supra note 11, at 349-50.

62. Id. at 347-48.

63. See Jonathan Rickford, A History of the Company Law Review, in THE REForm of UNITED KINGDOM COMPANY LAW 23-24 (John de Lacy ed., 2002) (discussing how the Company Law Review rejected wider stakeholder-oriented company law reforms as seen in the Companies Act of 2006). The Companies Act is an example of "enlightened shareholder value" because directors can take into account a wider range of issues when 
responsible, German model appears to be most notable for its retreat in recent years from its underpinning regulatory assumptions based on a social conception of the corporation and for its political desire to better emulate the Anglo-American model. ${ }^{64}$ Nonetheless, the reaction to Enron and other similar scandals in the early twenty-first century has created a culture of renewed interest in regulatory oversight for companies, which has been seen in the recent financial crisis. However, this is difficult to reconcile with the neoliberal demand for an open and deregulated corporate environment. In Europe, the compromise has been to use the more self-regulatory approach of English and EU Law, while the approach in the United States has been geared more toward mandatory regulation. 65

According to Calliess and Zumbansen, these imperatives are creating a process of transnationalization of corporate governance reform that is "characterised by its 'spatial' character, both with regard to its normative scope and its institutional origin." 66 This section of the article offers further evidence of this process and shows that some of the most important challenges come from fields of law and policy action, going beyond traditional national laws and corporate law itself. Thus, the challenge of corporate liability is being met by entrepreneurial public interest lawyers who are devising new forms of corporate liability litigation that seek to prove that the logic of company law should not prevent third parties from seeking redress through tort law or criminal law for certain classes of corporate wrongs, including human rights violations. Second, the U.N. Special Representative's framework for business and human rights shows that corporations may well have wider social responsibilities, including the observance of human rights, hitherto the exclusive concern of states. Third, in response to the global financial crisis and as a result of the rise of new state-owned MNEs from the BRICs, state ownership has resurfaced as a factor to be considered in the corporate law and governance universe. These

acting to further the success of their company including "the impact of the company's operations on the community and the environment." See further text at page 699 below.

64. See René Reich-Graefe, Changing Paradigms: The Liability of Corporate Groups in Germany, 37 CONN. L. REv. 785, 785-87 (2005) (discussing the shift from the "qualified concern" doctrine toward veil-piercing approaches in relationship to group liability); LEISTIKOW, DAS NEUE GMBH-RECHT 1-17 (2009) (discussing reform of the more restrictive elements of incorporation under $\mathrm{GmbH}$-Recht in response to competitive pressures from simpler incorporation laws in other EU countries, notably England, in the light of European court rulings allowing freedom of incorporation across the European Union).

65. See Muchlinski, supra note 46, at 743; CALLIESS \& ZUMBANSEN, supra note 3, at 194-227 (discussing the German Corporate Governance Code and EU approaches to corporate governance).

66. CALLIESS \& ZUMBANSEN, supra note 3, at 212. 
The Changing Face of Transnational Business Governance 685

developments strike at the heart of what asocial company law is doing and argue for a reunification between the company and society in law as well as in fact.

\section{A. The Challenge of Corporate Liability}

In the previous section, it was shown how the logic of corporate personality and limited liability restricts liability to third parties. This effect of company law has been criticized on the ground that it externalizes a risk that ought properly to be held by the company. Instead, the risk is passed to the involuntary creditor. This is wrong because the poorer risk taker assumes the burden of the risk, contrary to well understood notions of efficient risk allocation. ${ }^{67}$ The logic of company law externalizes the risk of liability away from the controlling interest by insulating it from liability except in the few cases where it can be shown that it has a direct involvement in the events leading to the violation. This position is reinforced by the highly restrictive conditions under which an Anglo-American judge will "pierce the corporate veil" and find the parent directly responsible for the acts of the subsidiary. Current law only permits this in cases of abuse of the corporate form. This excludes most tort cases where the parent is not directly involved in the course of events leading to the harm but is aware of the general situation, or ought to be so aware, but fails to prevent the harm from materializing. In these instances, "it may only be possible to hold the parent liable by showing that it was in actual control of the events that led to the injury and the resulting claims for compensation."68

Recent practice in both common law and civil law jurisdictions shows that there is a growing willingness among activist lawyers and NGOs to bring such claims against parent companies in their home countries. ${ }^{69}$ Such claims first arose in the United States and other common law jurisdictions and have become known as foreign direct liability claims. ${ }^{70}$

67. See Nina A. Mendelson, A Control-Based Approach to Shareholder Liability for Corporate Torts, 102 CoLUM. L. REv. 1203, 1217-25 (2002).

68. Muchlinski, supra note 44, at 919.

69. See Peter Muchlinski, The Provision of Private Law Remedies Against Multinational Enterprises: A Comparative Law Perspective, 4 J. CoMP. L., no. 2, 2009, at 148. My thanks to Brian Hill of Wildy, Simmonds and Hill Publishing for permission to reproduce material from this article.

70. See Halina Ward, Governing Multinationals: The Role of Foreign Direct Liability, 18 ROYAL INST. INT'L AFF. 1 (2001), available at http://www.chathamhouse.org.uk/ files/3028_roleoffdl.pdf. According to Ward, foreign direct liability is defined as "[a] new wave of legal actions in the UK, US, Canada and Australia [that] aims to hold parent companies legally accountable in developed country courts for negative environmental, health and safety, labour or human rights impacts associated with the operations of 
The origins of foreign direct liability litigation emerged from two sets of cases starting in the $1990 \mathrm{~s}^{71}$ First, there were the U.S. cases brought under the Alien Tort Claims Act (ATCA) that centered on alleged violations of human rights by corporate actors through their foreign operations. Second, a series of cases, brought before U.K., Canadian, and Australian courts, sought to hold the parent company accountable before the courts of the home state for wrongs committed by its subsidiaries abroad. Here, the emphasis was not so much on human rights abuses, though they may be an aspect of the case, but rather on civil law, especially tort liability under the laws of the home state.

The common law origin of such cases appears to be rooted in a number of culturally specific factors. American lawyers, and to a lesser extent their English, Australian, and Canadian counterparts, see legal practice in more entrepreneurial terms than lawyers who are steeped in the civilian tradition, who see themselves more as political actors dedicated to the defense of the public interest. ${ }^{72}$ Equally, the adversary system of justice encourages the placing of the interests of the client first and hands control over the presentation of evidence to the lawyers rather than to the court, as is the case in civilian systems. ${ }^{73}$ Both systems tend to give lawyers in these countries a sense of initiative to develop their own cases.

A further important factor arises from the fact that most of the leading NGOs concerned about corporate social responsibility were founded in the Anglo-American world. They have been at the forefront of activism in relation to foreign direct liability. ${ }^{74}$ Perhaps the best example is the U.K.-based Corporate Responsibility Coalition (CORE)

members of their corporate family in developing countries. These 'foreign direct liability' claims represent the flip side of foreign direct investment. They complement campaigners' calls for minimum standards for multinational corporations by testing the boundaries of existing legal principles, rather than by calling for new regulation." Id. See also Muchlinski, supra note 46 , at 745 .

71. See Ward, supra note 70 , at 2.

72. See Terence C. Halliday \& Lucien Karpik, Preface to LAWYERS AND THE RISE OF WESTERN POLITICAL LIBERALISM 13 (Terence C. Halliday \& Lucien Karpik eds., 1997) (identifying a new American model of legal practice after World War II that is strongly favored throughout the world due to the United States' economic and political influence and the energetic entrepreneurialism of U.S. lawyers). This influence is seen in particular in the building of market-based legal solutions to economic globalization but less so in relation to political and constitutional issues. A good example of this entrepreneurial domination is the prevalence of U.S. and UK law firms in international investor-state arbitration. See id.

73. See Stephen Gillers, The American Legal Profession, in Fundamentals OF AMERICAN LAW 151, 166-68 (Alan B. Morrison ed., 1996).

74. See Michael. YaZiJI \& JONATHAN DOH, NGOS AND CoRPorations: Conflict AND COLLABORATION 26-31 (2009). 
formed in 2000. It aims to make changes in U.K. company law to "minimise companies' negative impacts on people and the environment and to maximise companies' contribution to sustainable societies."75 Members of CORE include Amnesty International, Action Aid, Friends of the Earth, Traidcraft, War on Want, and WWF (U.K.). The main themes of the CORE's work include "the need for greater corporate accountability of key decision makers in companies, the importance of openness and transparency and better access to justice for victims of corporate abuse." 76 In this connection, CORE advocates the reform of English law to further accommodate foreign direct liability through changes in statutory obligations of corporations and through litigation. ${ }^{77} \mathrm{~A}$ similar strategy was undertaken in Canada where a private member's bill, Bill C-300 entitled "An Act respecting Corporate Accountability for the Activities of Mining, Oil or Gas in Developing Countries," sought to establish a ministerial reporting procedure before Parliament under which the human rights and environmental standards compliance of Canadian companies in the energy and natural resources industry would come under scrutiny. ${ }^{78}$ By mid-June 2010 , the bill had passed through first and second readings and through committee hearings. Bill C-300 went to a third reading and a final vote in October 2010 and was defeated by just six votes. ${ }^{79}$

Foreign direct liability litigation is also now appearing in civil law jurisdictions. In recent years, under the leadership of the human rights' NGO Sherpa, a number of cases have been commenced against French MNEs for alleged violations of human rights by their overseas subsidiaries. ${ }^{80}$ However, the validity of foreign direct liability claims

75. FTSE100 Company Reports Reveal Inadequacy of Companies Act, CoRPORATE RESPONSIBILITY, http://corporate-responsibility.org/about/ (last visited May 11, 2011).

76. Id.

77. See CORE COALITION, THE REALITY OF RightS: BARRIERS TO ACCESSING REMEdies WHEN BUSINESS OPERATES BEYOND BORDERS 5-6 (2009), available at http://corporateresponsibility.org/wp/wp-content/uploads/2009/08/reality_of_rights.pdf.

78. Corporate Accountability of Mining, Oil and Gas Corporations in Developing Countries Act, H.C. 2009, c. 300 (Can.).

79. Liezel Hill, Canadian Lawmakers Vote Down Controversial Bill C-300, MINING WEEKLY (Oct. 28, 2010), http://www.miningweekly.com/article/canadian-mps-vote-againstbill-c-300-2010-10-28.

80. See L'association, SHERPA, http://www.asso-sherpa.org/association/notre-mission (last visited Apr. 2, 2011) (explaining Sherpa's mission of protecting and defending victims of economic crimes through legal action). Claims were lodged in 2002 against Rougier in respect of alleged corrupt practices in Cameroon, but were dismissed by the Paris Court of Appeal on February 13, 2004, on the ground of lack of jurisdiction over the parent company for the acts of its subsidiary. Claims were lodged against Total arising out of its involvement in the construction of the Yadana pipeline in Burma. Investigations are being 
remains uncertain in France. Civilian legal systems generally view a criminal trial and conviction as the requisite basis for compensation in grave human rights abuse cases. ${ }^{81}$ Equally, in the recent Lipietz litigation, a case concerning the extent to which the French national railway company, SNCF, and the French government could be held responsible for complicity in the deportation of French Jews during World War II, the liability of both was accepted at first instance, but SNCF's liability was overturned on appeal..$^{82}$ The Conseil d'Etat upheld the Administrative Court of Appeals on the ground that the tribunal of first instance lacked jurisdiction to hear a civil claim against SNCF, which was, at the relevant time, a mixed-economy entity exercising both public and commercial functions, and on the ground that it was acting under orders as the Court of Appeals had correctly concluded. ${ }^{83}$

More recently, in the Netherlands, victims of oil pollution from Shell's installations in Nigeria, in conjunction with Milieudefensie (Friends of the Earth Netherlands), have started legal proceedings against Shell Nigeria and Royal Dutch Shell PLC, its parent company. 84 The claimants allege that Shell Nigeria is liable for the pollution as the operator of the relevant plants in the Niger Delta, while Royal Dutch Shell is liable as the parent company and is therefore responsible for preventing environmental damage on the part of its subsidiary. This principle of liability is supported, according to the claimants, in other legal systems, especially in U.S. and English law, as well as under Dutch law and under international standards contained in international soft law instruments such as the OECD Guidelines on Multinational

conducted with a view to future litigation in a number of new cases. See Muchlinski, supra note 69 , at 160 .

81. See Vivian Grosswald Curran, Gobalization [sic], Legal Transnationalization and Crimes Against Humanity: The Lipietz Case, 56 AM. J. CoMP. L. 363, 379 (2008).

82. See Le tribunal administratif [regional administrative court of first instance] TA Toulouse, June 6, 2006, 0104248 (Fr.), available at http://www.haguejusticeportal.net/ Docs/NLP/France/Lipietz_jugement_6-6-2006.pdf (for an unofficial English translation of the Lipietz case by Anne Witt, J.D. and legal translator, as revised by Vivian Grosswald Curran, Professor of Law at the University of Pittsburgh, visit http://www.acaccia.fr/IMG/pdf/JudgmentLipietzenglish.pdf); Curran, supra note 81, at 363-64.

83. Madame Lipietz and others for the Counseil d'Etat reasoned that the administrative court of appeals had not erred in its finding that the administrative court of Toulouse lacked jurisdiction because SNCF was a company endowed with a mission of public service and was acting in convention thereof and not in its modern commercial purpose. Conseil d'Etat [highest administrative court], CE, Nov. 28, 2007, 305966, Mme. L. et autres, available at http://www.conseil-etat.fr/cde/node.php?articleid=1485.

84. See Factsheet for The People of Nigeria Versus Shell: The Course of the Lawsuit, MILIEUDEFENSIE (Dec. 2009), http://www1.milieudefensie.nl/english-/publications/The\% 20 course $\% 20$ of\%20the\%20lawsuit.pdf. 
Enterprises and the U.N. Global Compact and Global Reporting Initiative. ${ }^{85}$ On December 30, 2009, the Civil Court of the Hague ruled that the claimants had the right to bring the case before a Dutch court. ${ }^{86}$ This is the first time a Dutch court has accepted jurisdiction over a foreign direct liability claim.

Foreign direct liability may be seen as an antidote to one of the more undesirable results of a shareholder primacy model of corporate law. With its emphasis on the total legal separation between the shareholder and the corporation, the shareholder primacy model permits the shareholder to escape responsibility for wrongs committed by the company in which it holds a stake. It is the very aim of foreign direct liability litigation to subvert this assumption and to render the controlling interest liable for the acts of its subsidiary, especially as the parent and subsidiary are in economic terms a single enterprise. Indeed, even when the shareholder is a natural person, it is strongly arguable that he or she should also bear some measure of responsibility for corporate wrongs if he or she is to enjoy the benefits of shareholder rights in the company. 87

Equally, with its transnational qualities of "legal sampling," 88 this development challenges the idea that transnational corporate actors can benefit from different levels of liability in different jurisdictions. Litigation strategies are increasingly used as part of a wider political strategy to mobilize opposition to the social and political effects of globalization on local communities. This has resulted in what de Sousa Santos has termed "subaltern cosmopolitan legality," the process by which excluded and marginalized groups use existing laws in a counterhegemonic way to undermine the dominance of institutions and practices that seek to further the interests of the minority of social actors who benefit from globalization. ${ }^{89}$ One part of such a strategy is to

85. Oruma Subpoena of 2008 ๆ $203-228$, available in English at http://www.milieudefensie.nl/globalisering/publicaties/infobladen/Scan\%20dagvaarding\%2 0Oruma\%20Engels.pdf.

86. Oruma v. Royal Dutch Shell PLC (Nig. v. Neth.), Dec. 30, 2009, (Hague Ct.), http://zoeken.rechtspraak.nl/default.aspx (input BK8616 for LJN).

87. See Paddy Ireland, Limited Liability, Shareholder Rights and the Problem of Corporate Irresponsibility, 34 CAMBRIDGE J. ECONOMICS 837 (2008) (discussing the history of limited liability and the creation of the doctrine of separate corporate personality).

88. Legal sampling occurs when activist lawyers build upon the experiences of other jurisdictions and attempt to develop forms of foreign direct liability suitable to their own jurisdictional realities.

89. Boaventura de Sousa Santos, Toward a New Legal Common SENSE 180-81 (2002). See Boaventura de Sousa Santos \& César A. Rodríguez-Garavito, Law, Politics, and the Subaltern in Counter-Hegemonic Globalization, in LAW AND GLOBALIZATION FROM BELOW: TOWARDS A Cosmopolitan LegaldTy 1, 12-18 (Boaventura de Sousa Santos \& César A. Rodríguez-Garavito eds., 2005). 
further litigation against MNEs either in the host country, where the alleged wrongs have taken place, or in the home country of the parent, emphasizing the responsibility that comes from the operation of an integrated transnational enterprise regardless of the formal corporate separation between parent and subsidiaries.

\section{B. The Challenge of Human Rights Responsibility}

The global economic crisis has created a situation in which those affected by the crisis become more vulnerable than ever to potential harm caused by human rights abuses. This includes abuses suffered at the hands of corporate actors. According to Special Representative Ruggie:

Markets can be highly efficient means for allocating scarce resources, and powerful forces for promoting social objectives ranging from poverty alleviation to the rule of law. But for markets to work optimally they must have adequate institutional underpinnings and be embedded in the broader values of social community. All along [the Special Representative] has stressed that these governance gaps "create the permissive environment within which blameworthy acts by corporations may occur without adequate sanctioning or reparation." [The Special Representative] employed this framing to explain the state of business and human rights. We now know it holds for the world political economy as a whole..$^{90}$

This is a direct challenge to the asocial corporation. Indeed, in his 2008 Report to the Human Rights Council, Special Representative Ruggie made clear that the failure of companies to meet their responsibility to respect human rights,

can subject companies to the courts of public opinion comprising employees, communities, consumers, civil society, as well as investors - and occasionally to charges in actual courts. Whereas governments define the scope of legal compliance, the broader scope of the responsibility to respect is defined by social expectations

90. U.N. Special Rep. of the Secretary-General, Business and Human Rights: Towards Operationalizing the "Protect, Respect and Remedy" Framework, I 7, U.N. Doc. A/HRC/11/13 (Apr. 22, 2009) [hereinafter Business and Human Rights]. 


\section{The Changing Face of Transnational Business Governance 691}

- as part of what is sometimes called a company's social licence to operate. ${ }^{91}$

Thus the Special Representative clearly sees a social context for the operations of corporate investors in host countries - a social license to operate.

The main means by which corporations are to exercise their responsibility to respect human rights is through the application of a due diligence mechanism to human rights risk assessment. This requires the company to move from being a victim of "naming and shaming" to "knowing and showing" that they understand and internalize human rights through due diligence. ${ }^{92}$ The main elements of due diligence include: a full human rights policy, periodic assessments of human rights impacts, and proper control and reporting systems that stress effective corporate grievance procedures. Special Representative Ruggie has stressed that this is not like other commercial due diligence processes, which are in the main transactional processes, as there is a constant need to engage in communication with the right-holders..$^{93}$ In other words, the firm must look beyond the protection of its own interests and focus on the interests of those it affects by its actions. ${ }^{94}$ The legal implications of due diligence are also considered. In particular, Special Representative Ruggie has argued that properly conducted due diligence will provide strong protection against mismanagement claims by shareholders and give proof that the company took every reasonable step to avoid a violation, which should count in its favor in litigation. ${ }^{95}$ However, the Special Representative has rejected the notion that human rights due diligence should automatically absolve the company from liability under, for example, the Alien Tort Claims Act in the United States. ${ }^{96}$

The introduction of a responsibility to respect human rights and the development by companies of a human rights due diligence mechanism, as suggested by the Special Representative, may also result in certain reforms of corporate organization. In particular, the development of human rights compliance systems and managerial structures to achieve

91. U.N. Special Rep. of the Secretary-General, Protect, Respect and Remedy: a Framework for Business and Human Rights, If 54, U.N. Doc. A/HRC/8/5 (Apr. 7, 2008).

92. U.N. Special Rep. of the Secretary-General, Business and Human Rights: Further Steps Toward the Operationalization of the "Protect, Respect and Remedy" Framework: Special Report of the Secretary-General, If 80, U.N. Doc. A/HRC/14/27 (Apr. 9, 2010) [hereinafter Ruggie Report].

93. Id. at I 85 .

94. Id. at $₫ 81$.

95. Id. at I 86 .

96. Id. 
this may become a feature of the reformed human rights oriented "civil corporation." 97 The introduction of managerial obligations to perform human rights due diligence is also likely to develop into a binding legal duty of care under tort law for both management and the corporation and will be a significant addition to the protection of involuntary creditors. ${ }^{98}$ It will recognize that they have an unanswerable moral claim to consideration in corporate decision making based on the established and evolving standards of corporate responsibility in both national and international law. ${ }^{99}$

\section{The Challenge of Direct State Involvement in and with Corporations}

The impact of state involvement in corporate action is extensive. Indeed it is arguable that without the state the capitalist system cannot function. 100 The real question is how extensively the state should be involved, which is an issue of balance, not of alternatives, between the state and the market.101 In recent years, the state is said to have retreated from the economy, whether through the privatization of stateowned enterprises (SOEs), through deregulation or market liberalization. This is both a domestic and an international process. ${ }^{102}$ Yet, in recent years, the state has moved back into the economic fray as an owner of enterprises, an investor, and a regulator. As noted at the beginning of this article, this is in part a forced response to the financial crisis but is also indicative of an increased number of SOEs that are also MNEs from the BRICs and other newly globalizing economies, as well as the increased presence of SWFs as investment vehicles. It is not possible to cover all the implications of these developments here. Rather, the emphasis will be on how the increased role of the state affects the further development of transnational corporate governance. This will be considered by way of a study of the U.K. policy of state

97. See Simon ZADEK, The CIVIL CoRPoRATION 36-41 (rev. ed. 2007).

98. See Peter Muchlinski, Implementing the New UN Corporate Human Rights Proposals: Implications for Corporate Law, Governance and Regulation, BUS. ETHICS Q. (forthcoming 2011).

99. On which, see further Wesley Cragg, Business Ethics and Stakeholder Theory, 12 BUS. ETHICS Q. 113 (2002).

100. See DICKEN, supra note 34, 169-220 (discussing that although the role of the state has changed, it still plays a significant role in the economy). The state plays four key roles: (1) containers of distinctive institutions and practices, (2) regulators of economic activities and transactions, (3) competitors with other states, and (4) collaborators with other states. 101. See Martin Kettle, Problems This Big Need More Than the State v Market Stuff, GUARDIAN (U.K.), Mar. 20, 2009, available at http://www.guardian.co.uk/ commentisfree/2009/mar/20/climate-change-politics-capitalism?NTCMP=SRCH\#box.

102. See MARTIN WOLF, WHY GLOBALIZATION WORKS 61-67 (2004). 
shareholding in the banking sector and by consideration of the impact of SOE activities in the global economy.

In response to the banking crisis that occurred from 2007 to 2009 , the U.K. government acquired controlling interests in failing banks. It outright nationalized Northern Rock and the Bradford and Bingley, while the rescue of Royal Bank of Scotland (RBS) and Lloyds TSB/HBOS resulted in an eighty-three percent government shareholding in the former and a forty-one percent shareholding in the latter. ${ }^{103}$ These full or partial state holdings of stock are in the hands of a special company set up by the British government, U.K. Financial Investments Ltd. (UKFI). ${ }^{104}$ UKFI defines itself as,

a Companies Act Company, with HM Treasury as its sole shareholder. The company's activities are governed by its board, which is accountable to the Chancellor of the Exchequer and-through the chancellor-to Parliament. Membership of the UKFI board comprises a private sector Chair, non-executive private sector members, a Chief Executive and senior Government officials. ${ }^{105}$

The operation of UKFI is governed by a shareholder relationship framework document concluded between the company and HM Treasury. ${ }^{106}$ The most significant element of this framework is that, unlike traditional nationalizations of the past, its aim is to return the state shareholding in the banks to the private sector as soon as possible. ${ }^{107}$ With this aim in mind, UKFI will draw up an "investment mandate" that will seek to create the best return for taxpayers in the

103. See UK Financlal InVestments LTD., ANNUAL RePORT AND ACcounts 2009/10, H.C. 312 , at 19, 24. See also N. Jansen Calamita, The British Bank Nationalizations: An International Law Perspective, 58 INT'L \& CoMP. L. Q. 119 (2009) (explaining the international legal implications of these nationalizations).

104. See About Us, UK FINANCIAL INVESTMENTS LTD., http://www.ukfi.co.uk (last visited Mar. 21, 2011).

105. Id.

106. UK Financial InVestments LTD., Shareholder Relationship Framework DOCUMENT If 1 (rev. 2009), http://www.ukfi.co.uk/releases/Framework\%20Document \%20July\%20Revised\%20Version.pdf.

107. Id. at I 3.1 ("The Company should, in compliance with the Investment Mandate described in Section 4 (The Investment Mandate), develop and execute an investment strategy for disposing of the Investments in an orderly and active way through sale, redemption, buy-back or other means within the context of an overarching objective of protecting and creating value for the taxpayer as shareholder and, where applicable, as provider of financial support, paying due regard to the maintenance of financial stability and to acting in a way that promotes competition."). 
management of the state-held and -controlled banks. ${ }^{108}$ The relationship between the UKFI and the banks is like a commercial investment manager and not like an executive manager involved in the day-to-day affairs of the banks. In the case of the wholly-owned banks, the role is carried out

in a manner similar to that in which a financial sponsor would engage with a wholly-owned portfolio company. The Company will, in addition to the rights attaching to the Investments in these companies but subject to the other provisions of this Framework Document, exercise all rights and discretions conferred on the Company under the applicable Investee Company Framework Document. ${ }^{109}$

Two overriding objectives inform the corporate governance of UKFI and its operation of the state shareholdings in the banks: the avoidance of anticompetitive practices and the appropriate management of conflict and insider information. To this end, there are controls over crossdirectorships in state-owned and -controlled banks, barriers to inside information leaks between the banks, and compliance procedures for financial services regulation. ${ }^{110}$ In addition, UKFI has powers to "develop a robust assurance regime for monitoring and securing compliance with the Business Plans and Investee Company Conditions, and will regularly discuss its approach with HM Treasury and report on compliance to HM Treasury."111

This structure has arisen as a response to crisis. Thus, it is not an ideologically inspired policy, unlike the mass nationalizations under the Atlee government of 1945 through 1951, which were described as the Labour Party's "long-standing electoral aims being translated into legislation."112 However, the U.K. banking sector will face the same dangers of politicization as the earlier nationalized industries. Indeed, the question remains whether UKFI should insist that the banks under its control act as social investors, helping to create new jobs and industries, or whether it can credibly continue to oversee a purely commercial operation, aimed at early reprivatization, which may again reproduce the excesses and lack of due diligence that led to the financial crisis in the first place.

108. See id. \ 4 (explaining terms and conditions of the Investment Mandate).

109. $I d$. $7.2(\mathrm{~A})$.

110. Id. ๆ 7.3 .

111. Id. ๆ 8.2 .

112. Cento Velatanovski, Seluing the State: Privatisation in Britain 54 (1988). 


\section{The Changing Face of Transnational Business Governance 695}

The call for a more socially oriented financial sector is exemplified by a recent campaign run by the Green Investment Bank Commission to reorganize RBS into a government-sponsored Green Investment Bank (GIB) or Royal Bank of Sustainability.113 It is argued that the government should not miss this opportunity to redefine the role of banks in society and avoid the possible return to short-termism. ${ }^{114}$ Given that at least $£ 200$ billion has to be invested in U.K. energy infrastructure in the next ten to fifteen years, and that this sector could generate many new jobs, the GIB could lead the way and provide the financing for this. The new Coalition Government has indicated in the Coalition Government Agreement of May 12, 2010, that they would support the creation of a GIB.115 From a corporate governance perspective, this proposal contains a major problem. While eighty-three percent of the stock in RBS is government owned, the remainder is not. These minority shareholders have the right to have their interests considered as well. If they do not have a cause of action against RBS, the commercial, as well as the social, case for the creation of the GIB out of RBS would need to be made. Again, the logic of enhanced shareholder value is present. Of course the state could buy out the remaining minority and have full control. Then, RBS would be free to do as its controlling state owner wishes. However, the actual corporate governance structure and mandate of UKFI suggests that such action is impossible. The U.K. framework has not challenged the dominant market-led model, though with political will it is easy to see how this could change.

Turning to multinational SOEs, many of the new players in the global economy are so constituted. For example, the national petroleum companies of a number of developing countries are developing international investment strategies. 116 The state-owned Russian energy

113. See James Leaton, A Bank for the Future: MaXimising PUBlic Investment in a LOW-CARBON ECONOMY 20-22 (2010), available at http://www.wdm.org.uk/sites/ default/files/A\%20Bank\%20for\%20the\%20Future.pdf.

114. Id. at 15 .

115. Id. at 29.

116. Examples include: Petrobras (Brazil 100\% state owned), Pemex (Mexico 100\%), and Petroleos de Venezuela (100\%). Jean-PierRe Anastassopoulos ET al., STATE-OWNED MUlTinationals 183-84 (Valerie Katzaros trans., 1987). See also LoUIS TURNER, OIL COMPANIES IN THE INTERNATIONAL SYSTEM 237-39 (3d ed. 1983); Oil's Dark Secret, ECONOMIST, Aug. 10, 2006, at 67; Member Countries, OPEC.ong, http://www.opec.org/opec_web/en/about_us/25.htm (last visited Mar. 21, 2011) (listing several developing countries as members of the Organization of the Petroleum Exporting Countries (OPEC)). The China National Offshore Oil Corporation (CNOOC) is majority state owned. Its state ownership was one of the reasons that the U.S. Congress was concerned about its aborted takeover proposal of the U.S. oil company Unocal. See James 
and natural resources companies Gazprom and Rosneft are extending their international operations. Similarly, Embraer of Brazil established itself as an international aerospace company while in state ownership. ${ }^{117}$ The state may be a useful partner when the private sector is virtually nonexistent, as in developing countries or countries in transition from a socialist command economy. ${ }^{118}$ However, the downside is that state involvement may create the perception that the SOE is no more than an arm of the home state. Thus, some see Gazprom and Rosneft as instruments of Russian foreign policy. ${ }^{119}$ This may disadvantage the SOE commercially. For example, the state ownership of the China National Offshore Oil Corporation (CNOOC) was instrumental in stopping the company from bidding for a stake in the U.S. oil and gas company Unocal. CNOOC took the unusual step of filing a unilateral notice to the Committee for Foreign Investment in the United States (CFIUS) ${ }^{120}$ without Unocal, which was by now committed to a takeover by U.S.-based Chevron. CFIUS did not have to rule on the bid because CNOOC decided to withdraw its bid in response to Congressional pressure. ${ }^{121} \mathrm{Fu}$ Chengyu, the chair and chief executive of CNOOC, has suggested that a reduction in the Chinese government's

Boxell \& Kevin Morrison, Oil 'Majors' Find New Rivals Snapping at Their Heels, Fin. TIMES (London), Dec. 8, 2004.

117. About Embraer, EMBRAER, http://www.embraer.com/en-US/ConhecaEmbraer/ tradicaohistoria/Pages/Home.aspx (last visited Jan. 21, 2011). Embraer was founded by the Brazilian government in 1969. It was privatized on December 7, 1994. Embraer Timeline, EMBRAER, http://www1.embraer.com.br/timeline/english/ (last visited Mar. 16, 2011).

118. Developing countries may retain public ownership where the alternative is domination of an industry by foreign capital. However, in the long term the pressures of state control may force privatization to occur. Short of privatization, reforms aimed at increasing managerial efficiency may be taken. See generally WORLD BANK, WORLD DEVELOPMENT REPORT 1983 (1983) (discussing the World Bank's financing programs with developing countries); PETER Evans, EMBEDdED AUTONOMY: STATES AND INDUSTRLAL TRANSFORMATION (1995) (studying state involvement in promoting the computer industries in Brazil, India, and Korea in the 1970s and '80s); ATUL KOHLI, STATEDirected Development: Political Power and Industrialization in the Global PERIPHERY (2004) (providing an analysis of the role of the state in industrialization of developing countries).

119. See Ivan at the Pipe: Russia's Energy Firms are Viewed with Suspicion as They Try to Expand in Former Communist Countries, ECONOMIST, Dec. 9, 2004, available at http://www.economist.com/node/3471333; Oil's Dark Secret, supra note 116.

120. CFIUS is charged with the reviewing of bids for U.S. companies involving national security concerns under the Exon-Florio Amendment to the U.S. Defense Production Act of 1950 .

121. See Edward M. Graham \& David M. Marchick, US National Security and FOREIGN DIRECT INVESTMENT 135-36 (2006). 
holding would combat claims that the company was an instrument of government energy policy rather than a commercial company. ${ }^{122}$

Major issues of transnational corporate governance emerge from the question of whether an SOE is a political or commercial entity. One solution may be to view an SOE as no different than any other type of MNE and expect the same standards of corporate governance and responsibility. Indeed, the OECD Guidelines on MNEs make no distinction between private or state-owned enterprises in regard to the applicability of the norms they espouse. According to the current version of the OECD Guidelines, MNEs

usually comprise companies or other entities established in more than one country and so linked that they may co-ordinate their operations in various ways. While one or more of these entities may be able to exercise a significant influence over the activities of others, their degree of autonomy within the enterprise may vary widely from one multinational enterprise to another. Ownership may be private, state or mixed. ${ }^{123}$

There is a certain symmetry between private and state-owned MNEs insofar as both can own and operate a transnational enterprise network and achieve a measure of autonomous power. They may also create similar principal-agent problems as they conduct their internal operations, as the issue of minority shareholders in U.K. statecontrolled banks shows. However, it is clear that state participation and control creates greater political effects than those resulting from interactions between private enterprises and between enterprises and states. ${ }^{124}$ Thus, distinctive corporate governance and corporate regulation laws may be needed to deal with multinational SOEs. In a number of countries this is the case, though the main focus is on SWFs rather than SOEs. ${ }^{125}$

In regard to corporate social responsibility, direct state participation in business may allow for greater leverage over corporate activity in the public interest, at least in relation to enterprises from accountable, democratic countries. Such is the logic of the GIB proposal. By contrast, enterprises from nondemocratic countries raise problems in this regard.

122. Francesco Guerrera \& Richard McGregor, CNOOC Willing To Ask Beijing To Reduce Stake, FIN. TIMEs (London), Oct. 27, 2005, at 28.

123. OECD, OECD Guidelines for Multinational Enterprises, at 12 (2008), available at http://www.oecd.org/dataoecd/56/36/1922428.pdf [hereinafter OECD Guidelines].

124. See Cata Backer, supra note 2, at 69 .

125. See id. at 74-85. 
They have no homegrown tradition of corporate responsibility. Yet, when they venture abroad, different expectations may arise. Here, a lack of openness and transparency that is acceptable at home may prove wholly unacceptable. ${ }^{126}$ Equally, host countries may demand greater commitments to corporate social responsibility. Some new players are responding to these issues. For example, both Pemex of Mexico and Petrobras of Brazil have strong commitments to social development programs in their host country operations. ${ }^{127}$ Both firms come from countries where civil society groups demand social responsibility and where corporate cultures aspire to a level of global acceptance, as witnessed by the fact that both firms are members of the U.N. Global Compact. ${ }^{128}$ However, the issue remains alive for firms from other countries where such social and cultural conditions do not exist. Failure to respond and to operate in a socially responsible way could result not only in bad publicity but also in the extension of public interest litigation against such companies on the part of engaged lawyers and civil society groups.

\section{TOWARD A NEW MODEL OF TRANSNATIONAL SOCIAL CORPORATE LAW?}

The basic idea of a social model of corporate law is not new, nor is the critique of excessive shareholder protection under the law. ${ }^{129}$ What is new is the need to "resocialize" the corporation in the aftermath of the neoliberal experiment and its collapse. This requires not only the return to more stakeholder-oriented conceptions of corporate law and corporate liability, but also a wider reorientation of international economic law itself. The two can reinforce one another and ensure a more responsible system of transnational business relations. In particular, as will be argued below, BITs offer a way forward in this regard should the political will exist to include a corporate responsibility element in their provisions. The key to this process is the reassertion by the state of its duty to protect weaker social groups and individuals from irresponsible corporate power. To borrow a phrase from Ronald Reagan, "the market

126. WORLD INVESTMENT REPORT 2006, supra note 1, at 233.

127. Id.

128. Id.

129. See, e.g., WALTER RATHENAU, VOM AKTIENWESEN: EINE GESCHÄFTLICHE BETRACHTUNG (1917). Rathenau developed the concept of the "unternehmung an sich"the idea that corporations exist beyond their members and managers and are intertwined in the wider relations of society, thereby necessitating a broader set of goals than shortterm profit. THORSTEIN VEBLEN, ABSENTEE OWNERSHIP: BUSINESS ENTERPRISE IN RECENT TIMES: THE CASE OF AMERICA 11-39 (Transaction Publishers 1997) (1923); THORSTEIN VEBLEN, THE THEORY OF BUSINEsS ENTERPRISE 177-182 (Augustus M. Kelley Publishers 1975) (1904). 
The Changing Face of Transnational Business Governance 699

isn't the solution, it's the problem!" This is not to say that corporate law should return to some kind of revival of state-centric corporatism; that itself had been discredited as a policy tool by the end of the 1970s. ${ }^{130}$ However, a recalibration of international economic and corporate law geared toward a greater balance between facilitation and regulation of global business appears essential.

Such a perspective requires a recalibration of corporate law in line with wider stakeholder approaches to corporate governance. This approach has an older pedigree than agency approaches, but it has had little impact on contemporary regulatory developments. ${ }^{131}$ Indeed, the pressure on countries to adopt an Anglo-American enhanced shareholder value model has been intense in recent years, representing an integral part of the move toward the globalization of the neoliberal economic model. ${ }^{132}$ It has led some to assert the "End of History for Corporate Law." 133 With respect, history never ends, and with the global economic crisis placing in doubt the social and economic utility of the neoliberal project, the shareholder value model desperately needs to be reformed. The wholesale abandonment of enhanced shareholder value is rather unlikely given the embeddedness of the model in current corporate law and because of the continuing need to address the agency cost problem in modern corporations. However, the current model can evolve into a more widely based stakeholder approach in which the agency problems faced by shareholders will continue to be of importance, but the definition of shareholder value may have to be changed to allow for a more balanced consideration of all the classes of persons and groups that can be affected by corporate action.

130. See, e.g., VELJANOVSKI, supra note 112 , at $48-49,60$ (discussing the failure of nationalized industries in the United Kingdom).

131. See Thomas Clarke, Introduction: Theories of Governance - Reconceptualizing Corporate Governance Theory After the Enron Experience, in THEORIES OF CORPORATE Governance: The Philosophical Foundations of Corporate Governance 1, 4-8, 10 11 (Thomas Clarke ed., 2004). It should be noted that early English companies, such as Cadbury, were set up by owners who sought to develop socially responsible businesses, in this case to bring chocolate and barley-based products to the market as an. alternative to alcohol! See ANDREW SIMMS \& DAVID BOYLE, EMINENT CORPORATIONS: THE RISE AND FAIL OF THE GREAT BRITISH BRANDS 83.85 (2010).

132. See William Lazonick \& Mary O'Sullivan, Maximizing Shareholder Value: A New Ideology for Corporate Governance, 29 ECON. \& Soc'Y 13, 13-14 (2000).

133. "The triumph of the shareholder-oriented model of the corporation over its principal competitors is now assured, even if it was problematic as recently as twenty-five years ago. . . . We predict, therefore, that as European equity markets develop, the ideological and competitive attractions of the standard model will become indisputable, even among legal academics. And as the goal of shareholder primacy becomes second nature even to politicians, convergence in most aspects of the law and practice of corporate governance is sure to follow." Hansmann \& Kraakman, supra note 5, at 67-68. 
The key feature of the stakeholder approach is that it recognizes the company as an institution rather than a bundle of assets, one which must consider the needs not only of internal stakeholders, such as the shareholders, managers, and employees, but also the external stakeholders, such as customers, suppliers, competitors, and other special interest groups. ${ }^{134}$ Thus, a more socially rooted approach to decision making is required. In turn, this demands governance laws that permit a wider view to be taken. For example, continental European models of corporate governance often allow for worker participation in corporate affairs whether through works councils or the use of codetermination laws that require a certain proportion of the board to consist of worker representatives. ${ }^{135}$ Under the Anglo-American model, wider stakeholder interests can be introduced through the appointment of suitable nonexecutive directors to the board. ${ }^{136}$ Equally, the use of social accounting devices may assist. ${ }^{137}$ Arguably, English law is beginning to do so through the so-called "enlightened shareholder value" approach as exemplified by Section 172 of the Companies Act 2006, which, for the first time, accepts that directors may act in furtherance of the success of their company by considering, among other things, "172(1)(d) the impact of the operations on the community and the environment." 138 However, this is not a major change as Section 172 remains firmly focused on enhanced shareholder value in that the main duties of the director are still to "promote the success of the company for the benefit of its members as a whole."139

Turning to international economic law, corporate responsibilities could be included in international investment law instruments. For example, corporate responsibility clauses could be introduced into future BITs. The Norwegian draft BIT of 2007 Article 32 entitled "Corporate Social Responsibility" states that the "Parties agree to encourage investors to conduct their investment activities in compliance with the OECD Guidelines for Multinational Enterprises and to participate in the United Nations Global Compact." 140

134. See R. Edward Freeman, The Politics of Stakeholder Theory: Some Future Directions, 4 BUS. ETHICS Q. 409, 414, 417 (1994). See further R. EDWARD FREEMAN ET AL., STAKEHOLDER THEORY: THE STATE OF THE ART (2010).

135. See MUCHLINSKI, supra note 11, at 354-59.

136. See id. at $342-49$.

137. See id. at 375-82.

138. BRENDA HANNIGAN, COMPANY LAW 213 (2d ed. 2009),

139. Id. at 210. For further discussion, see id. at 211-18.

140. Agreement Between the Kingdom of Norway and $D$ for the Promotion and Protection of Investments, Nor. art. 32, 191207 (draft version), available at http://www.regieringen.no/upload/NHD/Vedlegg/hoeringer/Utkast\%20til\%20modellavtale2 .doc. 
The Changing Face of Transnational Business Governance 701

According to the Norwegian Government Commentary to the Draft Agreement:

The obligation to comply with the OECD guidelines applies primarily to countries outside the OECD area since all OECD members as well as Argentina, Chile, Brazil and Slovakia have committed themselves to making such efforts. Norway has committed itself to making the guidelines known in Norwegian commerce and industry and to establishing a point of contact for review of complaints in connection with allegations of breaches of these guidelines by Norwegian companies. ${ }^{141}$

Apparently, this is the first express reference to corporate social responsibility in any international investment agreement, though the draft Multilateral Agreement on Investment (MAI) did consider, as an option, an annex including the OECD Guidelines. This clause encourages investors to follow the OECD Guidelines and the U.N. Global Compact. These instruments protect third party stakeholder interests such as labor rights, human rights, and environmental protection, as well as anticorruption. However, it is a best efforts provision. It is not a binding investor obligation provision that could form the basis of a claim by the host country on par with the investor rights provisions. ${ }^{142}$ The Norwegian government did not adopt the Norwegian model, ${ }^{143}$ but the mere fact that such a provision has been included in a model BIT is itself highly significant and may indicate that some countries are seriously considering a move toward a greater balance of rights and obligations so that other stakeholder interests are better protected. ${ }^{144}$

141. Comments on the Model for Future Investment Agreements $\$$ 4.6.3 (Dec. 19, 2007) (Nor.), http://www.regjeringen.no/upload/NHD/Vedlegg/hoeringer/2008/ Forklarende\%20vedlegg\%20(engelsk)\%20-\%20final.doc.

142. For one possible model of such an approach, see Howard Mann et al., IISD Model International Agreement on Investment for Sustainable Development, 20 ICSID REV. FOREIGN INV. L. J. 91 (2005), http://www.iisd.org/pdf/2005/investment_model_int_ handbook.pdf. For another model, see U.N. CONF. ON TRADE \& DEV., WORLD INVESTMENT REPORT 2003: FDI POLICIES FOR DEVELOPMENT: NATIONAL AND INTERNATIONAL PERSPECTTVES 155, U.N. Sales No. E.03.II.D.8 (2003).

143. See Damon Vis-Dunbar, Norway Shelves Its Proposed Model Bilateral Investment Treaty, INVEST. TREATY NEwS, June 2009, at 7 , http://www.iisd.org/itn/wpcontent/uploads/2009/06/ITN.June-2009.pdf.

144. Peter Muchlinski, Trends in International Investment Agreements: Balancing Investor Rights and the Right to Regulate. The Issue of National Security, 2008-09 Y.B. INT'L INV. L. \& POL. 35, 48. 
In South Africa's continued review of its BITs, both the South African Human Rights Commission and the Special Representative have made submissions urging the government to use the review as an opportunity to consider the human rights framework within which investment issues operate. ${ }^{145}$ In the words of Special Representative Ruggie,

$[R]$ ecent experience suggests that some investment treaty guarantees and contract provisions may unduly constrain the host Government's ability to achieve its legitimate policy objectives, including its international human rights obligations. That is because under threat of binding international arbitration, a foreign investor may be able to insulate its business venture from new laws and regulations, or seek compensation from the Government for the cost of compliance. ${ }^{146}$

Thus, the South African review is encouraged to explore ways in which these various objectives can be reconciled. The starting point is that human rights concerns should not be kept apart from wider commercial policy issues, including investment. One response has gone so far as to say that the South African government should "build its own internal capacity and policy coherence on the topic of investment, taking the protection and promotion of human rights and sustainable development as the point of departure for all future policymaking." 147 It remains to be seen whether the South African government will go so far.

A possible outcome of such discussions might be the inclusion of a human rights observance clause in BITs. This could ensure the direct effect of corporate human rights responsibilities under international

145. See Peter Muchlinski, Trends in International Investment Agreements 2008-2009: Review of the Model Bilateral Investment Treaties of Norway, South Africa and the United States, 2009-10 Y.B. INT'L INV. L. \& PoL. 41, 68 (2010). See also Submission from the South African Human Rights Commission ("the Commission") on the Department of Trade and Industry's Draft Bilateral Investment Treaty Policy Framework Review, at 1.3 (June 2009), http://www.reports-and-materials.org/SAHRC-submission-on-draft-bilateralinvestment-framework-Jun-2009.pdf; Special Representative of the U.N. SecretaryGeneral, Statement of the Special Representative of the UN Secretary-General on the Issue of Human Rights and Transnational Corporation and Other Business Enterprises to the Department of Trade and Industry, South Africa (Sept. 4, 2009), http://www.reportsand-materials.org/Ruggie-statement-to-S-Africa-Govt-re-review-of-BITs-4-Sep-2009.pdf.

146. Ruggie Report, supra note 92, I 30.

147. JUIIE MaUPIN \& MALCOLM LANGFoRd, SUbMisSION CONCERNING THE BILATERAL INVESTMENT TREATY POLICY FRAMEWORK REVIEW GOVERNMENT POSITION PAPER 4 (2009), available at http://www.elaw.org/system/files/Commentston+DTI+BITs+review+FINAL.pdf. 


\section{The Changing Face of Transnational Business Governance 703}

law. Such a clause could offer protection for compliance to the investor, with international human rights norms in their operations in the host country, and make noncompliance the basis of a claim against the investor by the host country or third parties directly affected by this. Such a claim could be made subject to a prior duty on the part of the third party to exhaust local remedies in the host country so that international remedies would be used only as a last resort. A clause of this type would undoubtedly meet strong corporate resistance on the ground that it would divert BITs from their primary role as investor and investment protection agreements. However, if adopted, it would provide considerable strength to a more stakeholder-oriented approach to corporate interests in international investment law.

In addition to BITs, other international economic policy instruments could be used to further socially responsible corporate behavior. For example, the state can use its control over export credit guarantees to require corporate responsibility undertakings and impact assessments as a condition for issuing political risk insurance. As a result of the 1999-2000 governmental review of its mission and status, the U.K. Export Credits Guarantee Department (ECGD) must now take into account the contribution of an investment to sustainable development and the promotion of human rights and good governance. ${ }^{148}$ MIGA also requires corporate social responsibility assessments of proposed insurance applications from foreign investors as a condition of obtaining cover. ${ }^{149}$ It undertakes an environmental and social due diligence

\footnotetext{
148. See EXPORT CREDITS GUARANTEE DEPARTMENT [ECGD], ECGD'S BUSINESS

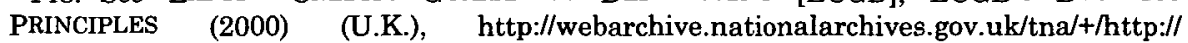
www.ecgd.gov.uk/ecgdbusprinciples.pdf; ECGD, REVIEW OF ECDG'S MISSIONS AND STATUS (2000) (U.K.), http://webarchive.nationalarchives.gov.uk/tna/+/http://www.ecgd.gov.uk/ missionstatusreview.pdf/; ECGD, SUSTAINABLE DEVELOPMENT ACTION PLAN: 2009-2011 (2009) (U.K.), http://www.ecgd.gov.uk/assets/bispartners/ecgd/files/publications/plans-andreports/sustainable-development-plans/ecgd-2009-11-sustainable-development-actionplan-final-2009-06.pdf.

149. See Multilateral Inv. Guarantee Agency [MIGa], Policy on Soclal \& ENVIRONMENTAL SUSTAINABILITY 2-3 (2007), http://www.miga.org/documents/environ_ social_review_021507.pdf ("In its operations, MIGA expects clients to manage the social and environmental risks and impacts of their projects. This entails the client's assessment of these risks and impacts, and implementation of measures to meet the requirements of the Performance Standards. An important component of the client's management of its social and environmental performance is the client's engagement with the affected communities through disclosure of relevant project information, consultation, and informed participation."). Social and environmental assessment is based on MIGA's standards. See MIGA, PERFormance STANDARDS ON SOcIAL \& ENVIRONMENTAL SUSTAINABILITY i (2007), http://www.miga.org/documents/performance_standards social_and_env_sustainability.pdf (enumerating the Performance Standards as follows: (1) Social and Environmental Assessment and Management Systems; (2) Labor and Working Conditions; (3) Pollution Prevention and Abatement; (4) Community Health, Safety and
} 
assessment before approving cover. ${ }^{150}$ Other approaches can also be used, such as developing a system that monitors and reviews corporate action to see if actions are in line with emerging international standards of corporate social responsibility and guidelines for MNEs. ${ }^{151}$ Finally, the Special Representative has recommended the establishment of a permanent office in the U.N. system to act as an advisory and capacitybuilding body on business and human rights, advising states, companies, U.N. organizations, and other national and international entities that the Special Representative has said regularly seek his advice regarding their own corporate-related human rights policies and practices. ${ }^{152}$

\section{CONCLUSION}

This article has focused mainly on private corporate law liability and accountability of transnational corporate actors. It locates this specific legal issue within the changing climate of opinion and policy relating to transnational corporate behavior. It calls for a reorientation of corporate law away from the neoliberal conception of the "asocial corporation" and the realization of the ideological goals of global financialization and enhanced shareholder value, toward the older tradition of the "socially embedded corporation." This is not the same as a return to outright corporatism or state socialism. Rather, it is an acknowledgement that some rebalancing between business facilitation and accountability is needed. The neoliberal approach has overemphasized facilitation over accountability.

The raising of accountability is occurring in diverse fora. This article has noted the steps taken by civil society groups, legal activists, and the harmed claimants who rely on their professional services, by way of

Security; (5) Land Acquisition and Involuntary Resettlement; (6) Biodiversity Conservation and Sustainable Natural Resource Management; (7) Indigenous Peoples; and (8) Cultural Heritage).

150. See Environmental and Social Impact Assessments, MIGA.oRG, http://www.miga.org/ policies/index_sv.cfm?stid=1655 (last visited Mar. 18, 2011) (outlining specific project information and providing due diligence assessments).

151. See, e.g., OECD Guidelines, supra note 123; HM GovernMENT, THE UK NATIONAL CONTACT POINT FOR THE OECD GUIDELINES FOR MULTINATIONAL ENTERPRISES (2009), http://www.berr.gov.uk/files/file53566.pdf.

152. Business and Human Rights, supra note 90, ๆๆ 125-26; see also U.N. Special Rep. of the Secretary-General on the Issue of Human Rights \& Transnational Corporations \& Other Business Enterprises, Recommendations on Follow-up to the Mandate (Feb. 11, 2011), available at http://www.business-humanrights.org/media/ documents/ruggie/ruggiespecial-mandate-follow-up-11-feb-2011.pdf (suggesting the establishment within the U.N system of a "Voluntary Fund for Business and Human Rights"). 
bottom-up recourse to existing legal devices and remedies, with the development of foreign direct liability. Such "subaltern legality" has created a demonstration effect that spurs on new initiatives in countries where such liability is yet to be determined. This bottom-up approach is complemented by the top-down approach of the U.N. Special Representative, who argues for corporate responsibility to respect human rights, supported by a state duty to protect human rights and promote effective remedies. In addition, the state is beginning to return as an active participant in global business and as a possible broker for corporate responsibility, at least in democratically accountable and socially responsible states. Should they wish, states can use their power, as owners and operators of SOEs, to control the tools of transnational economic ordering to enhance a new social corporate law. In addition, they may use their regulatory powers to introduce new forms of corporate responsibility in international economic law instruments and institutions. Thus, the process of "resocializing" the corporation can occur both at the national and transnational levels, which, as has been argued, are interlinked and complementary and which together are capable of building the new socially responsible transnational corporate governance. 
